\title{
The Biology of Balochistani Weed: Cyperus rotundus Linnaeus. A Review.
}

\author{
Abdul Hameed Baloch ${ }^{1 *}$, Haneef ur Rehman ${ }^{1}$, Zakir Ibrahim ${ }^{1}$, \\ Mohammad Aslam Buzdar ${ }^{2}$ and Saeed Ahmad ${ }^{1}$ \\ ${ }^{1}$ Faculty of Agriculture, Lasbela University of Agriculture, Water and Marine Sciences, Uthal Balochistan Pakistan. \\ ${ }^{2}$ Faculty of Marine Science, Lasbela University of Agriculture, Water and Marine Sciences, Uthal Balochistan \\ Pakistan. \\ *Corresponding author's email: hameedbaloch67@yahoo.ca Phone\# 92-853-610923 \\ Citation \\ Abdul Hameed Baloch, Haneef ur Rehman, Zakir Ibrahim, Mohammad Aslam Buzdar and Saeed \\ Ahmad. The Biology of Balochistani weed: Cyperus rotundus Linnaeus. A Review. Pure and \\ Applied Biology Vol. 4, Issue 2, 2015, pp 171-180. \\ Received: 06/02/2015 Revised: 23/04/2015 \\ Accepted: 04/05/2015
}

\section{Abstract}

Cyperus rotundus L. is considered one of the world's top 10 noxious weeds of agricultural fields of different economically important crops. Its rapid growth tendency and extensive underground rhizome/tuber system makes it extremely difficult to control. Although this weed also produces seeds but it mostly spreads by tubers. In this review, morphology, reproductive biology, economic importance, and different preventive measures of this weed are described in detail.

Keywords: Cyperus rotundus L.; Kullichk; tubers; phenolic compounds.

\section{Name}

Cyperus rotundus $\mathrm{L}$. is commonly known as Coco-grass, Java grass, nut grass, purple nut sedge, red nut sedge. Other common names include: Khmerkravanh chruk. It belongs to monocotyledonous family of Cyperaceae, (commonly known as sedge family) and is native to Africa, southern and central Europe and southern Asia. The word cyperus is derived from the Greek kyperos, and rotundus is from Latin, meaning round. C. rotundus is vernacularly (Urdu/Hindi) called Nagarmotha. In Punjab area of Pakistan it is called Deela [1]. In Balochistan it is commonly known as Kullichk, Kab/Kabb (Balochi, Brahui).

\section{Distribution}

C. rotundus is a noxious weed of tropical and subtropical regions of the world. It is reported in 52 different crops in 92 countries
[2]. C. rotundus mostly grows in shores, wet meadows, ditches, turf, ornamental areas, agricultural fields, moist road sides, sandy soils, river bottoms and waste places. In Pakistan, it is mostly reported in summer (Kharif) crops of cotton, rice, sugarcane and maize grown in the Indus valley $[2,3]$. In Balochistan it is mostly found in perennial canal based irrigated areas of Nasirabad Division, perennial and seasonal ravine tracts of Lasbela and Khuzdar districts and seasonal rain-fed agrarian areas of Nokbur (Kulanch area of Gwadar District).

\section{Morphological description}

Cyperus rotundus is a perennial, persistent and prolific weed of tropical, subtropical and temperate zones of the world. The plant has slender leaves and reaches the height of $20-60 \mathrm{~cm}$ and leaves are shorter than stem. Leaves are connected together with an 
underground modified stem which is commonly known as rhizome. Besides rhizomes, $C$. rotundus also produces tubers, basal bulbs and fibrous roots below ground. In early stages of growth the rhizomes are white and fleshy with crusty leaves and later on become fibrous, woody and dark brown with numerous long-creeping stolons [4]. Inflorescence is terminal (umbel) and flowers are numerous but these flowers produce only few seeds, therefore seeds are considered not the main source of propagation in C. rotundus [5]. The flowering period of $C$. rotundus is between April - October [6]. The underground modified parts e.g. rhizome, tubers and corms are the main sources of propagation of $C$. rotundus [5,7].

The morphological resemblance of $C$. rotundus with yellow nutsedge $(C$. esculentus L.) often causes confusion in identification. C. rotundus has brownish flowers, and its stolens occur in chains while C. esculentus has yellowish-brown flowers, and its stolens occur at the end of rhizomes.

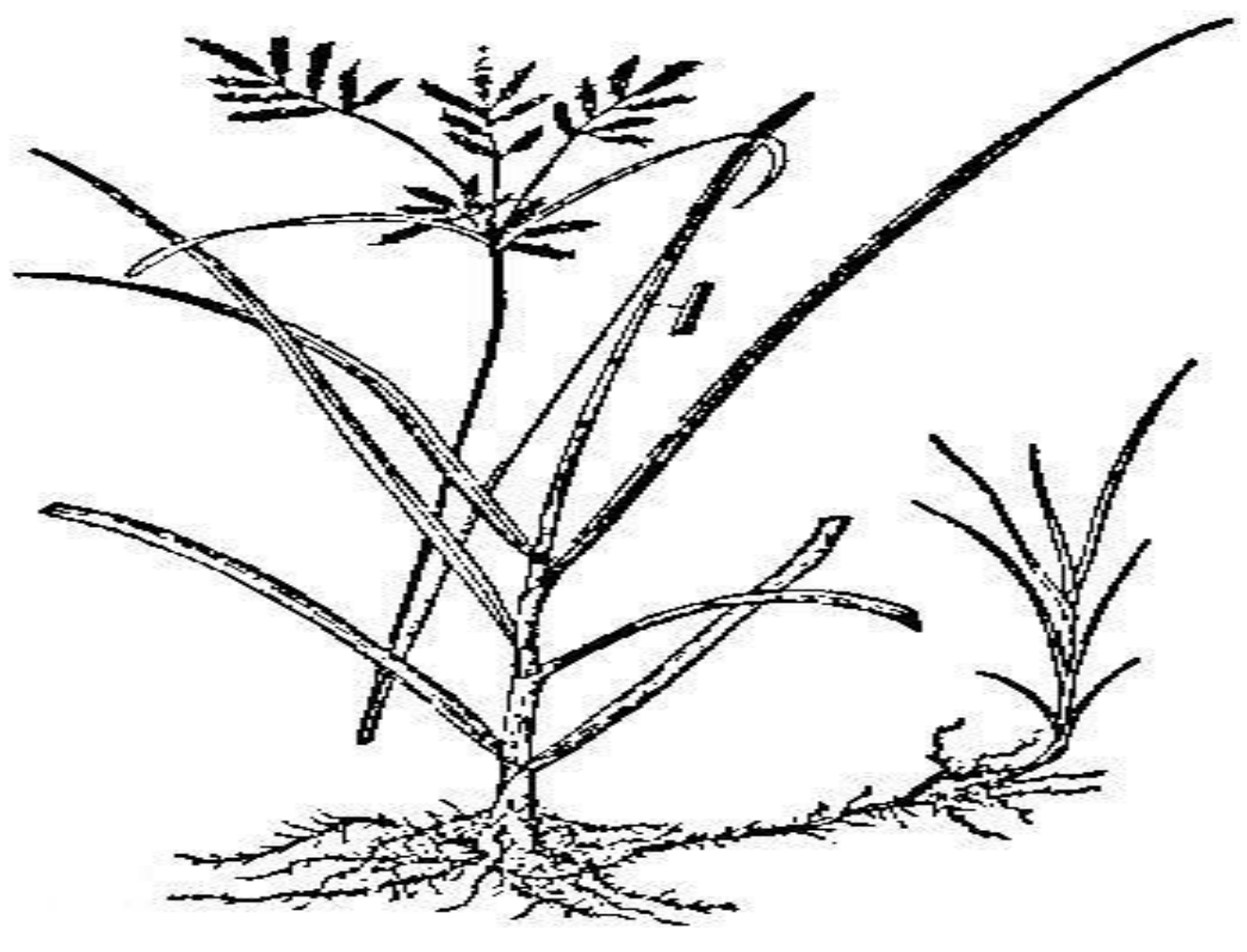

Figure 1. Cyperus rotundus (www.innerpath.com.au)

\section{Economical importance \\ 4.1 Detrimental}

C. rotundus is a native species of India and Pakistan [8], mostly distributed in disturbed areas as well as in agricultural fields. $C$. rotundus is considered as the most serious weed of different parts of the world $[5,9$,
10]. In Pakistan it is mostly reported in cultivated fields of rice [8], maize [11], sugarcane [12] and cotton [3, 13]. Similarly, Riaz et al. [14] and Iqbal et al. [15] also elaborated its deleterious negative impacts on different economically important crops of Pakistan. According to Lati et al., $C$. 
rotundus is a $\mathrm{C}_{4}$ weed, which is characterized by high photosynthetic efficiency and makes it a troublesome weed compared with $\mathrm{C}_{3}$ weeds [7].

C. rotundus has been quickly spreading in different agricultural fields due to modified underground storage vegetative parts i.e., tubers, which move from one area to another in soil with the help of agricultural equipment. It is reported that under favorable conditions, a single plant which arises from a single tuber can produce 100 or more tubers in about 100 days [5]. Similarly, about 80-95 percent of these tubers are to be found within the 6 inches of top soil and under constant moisture conditions these tubers remain viable for two years [5]. These tubers are light sensitive and once they are brought to the soil surface due to soil tillage than they lose the viability within a week. The polymorphism in tuber sizes is correlated with different levels of dormancy which is the most important adaptive factor that enables $C$. rotundus to cope with unfavorable environmental conditions. Therefore, dormancy plays an important role in survival of $C$. rotundus against herbicide applications or hand weeding.

The deleterious effects of $C$. rotundus on yields of different economically important vegetables and crops are reported by different researchers. Working on different vegetables, Keeley reported that the interspecific completion between $C$. rotundus and different vegetables showed negative impacts on yields of these plants. For example, there was an $89 \%$ reduction in yield of onion, $62 \%$ in okra, $39-50 \%$ in carrot, $43 \%$ in cucumber and $35 \%$ in cabbage when they grow in fields infested with $C$. rotundus [16]. Similarly, Santos et al. reported that there was a $70 \%$ yield loss in radish when grown in completion with $C$. rotundus [17].
Results of different researches conducted in different parts of the world also revealed that tubers of $C$. rotundus produced different chemical substances which show negative impacts on germination of different crops. According to Javid et al. tuber extract (10 and $15 \% \mathrm{w} / \mathrm{v}$ concentration) of $C$. rotundus reduced the germination of three rice verities, i.e. Pak Basmati, KS-282 and IRRI8 [8]. Moreover, the water extracts of tubers also reduced the seed germination and seedling growth of rice, corn, cucumber, tomato, sorghum and onion [18, 19]. Similar results were obtained by Verma et al. when they germinated mustard and tomato seeds in aqueous extracts of $C$. rotundus, which showed negative effects on seed germination, seedling growth and biomass production [20]. Similarly Alsaadawi and Salih observed that the tuber residues of $C$. rotundus drastically decreased the root and shoot growth of tomato and cucumber plants [21]. The chemical analysis of aqueous residue obtained from tubers and different parts of $C$. rotundus revealed that its leaves and tubers have 19 phenolic compounds [22] and also contain different sesquiterpenes [23]. These phenolic substances from leaf and tuber extract of $C$. rotundus showed negative impacts on germination and growth of competing plants [22]. The molecular studies showed that these allelochemicals reduced the growth of susceptible plant species when grown in competition with $\mathrm{C}$. rotundus by reducing the rate of mitosis [24].

\subsection{Beneficial}

C. rotundus is mostly treated as a noxious weed of different economically important crops of the world, however, in Asia particularly in India and China it is also considered as one of the most important medicinal plants which is traditionally in use for the cure of different ailments. The phytochemistry of $C$. rotundus tubers revealed the presence of polyphenol, 
flavonol glycoside, alkaloid, saponins, sesquiterpenoids and essential oils [25]. In oriental traditional medicine $C$. rotundus, is used as an antioxidant and antiinflammatory [26,27], anti-diabetic [28], anti-diarrheal [29], anti-malarial [30] and anti-pyretic and analgesic [31]. In Ayuveda and Chinese medicine plant extract of $C$. rotundus is used as a blood purifier in case of gynecological diseases which are caused by blood stagnation $[32,33]$. The tubers of C. rotundus are used to treat dysmenorrheal and menstrual irregularities [34]. It has been suggested that $C$. rotundus may have potential for wide spectrum activity in biological systems and have inhibitory effects on platelet aggregation [35]. According to Seo et al., the antiplatelet effects of Cyperus rotundus EtOH extract (CRE) was due to its active component (+)nootkatone which helps in preventing platelet-associated cardiovascular diseases [36].

The leaves of $C$. rotundus are used by local folks of Middle East and Southeast Asia to flavor food where it is an important component in their daily diet [36]. The seeds are also used as a curries and pickling spices in India and Southeast Asia. Seeds have digestive properties and are used for cure of minor digestive problems, and for hemorrhoids and painful joints [37]. The foliage parts and seeds of $C$. rotundus are rich in oily substances which are useful for cure of different ailments of digestive system, as well as stimulating the appetite and mitigating irritation [37]. It has been suggested that the oil extracted from $C$. rotundus has fungicidal and bactericidal properties. Experiments conducted by Nima, et al. was revealed that oil extract from leaves and seeds of $C$. rotundus has significant activities against gram-positive bacteria (Staphylococcus and Enterococcus) compared with gram-negative bacteria (Klebsiella pneumonia and Eschirichia coli) where less antibacterial activity was found [37]. From these results it was concluded that the cell wall of gram-positive bacteria contain lipopolysaccharides which is sensitive to oily substances of $C$. rotundus [38].

\section{Population Dynamics}

The purple nutsadge produces only few viable seeds which are generally responsible for the introduction of $C$. rotundus to a new area, however, tubers and rhizomes are the main sources of a local infestation. There is paucity of relevant scientific literatures on seeds behavior and germination of purple nutsadge and most of the researchers emphasized on the structure and behavior of tubers and rhizomes. Therefore it is imperative that seed behavior should be considered for future research which will be helpful in understanding of population dynamics of $C$. rotundus.

The morphological characteristics of $C$. rotundus make it relatively poor competitor, Iqbal et al. found $C$. rotundus to be more susceptible to interspecific competition than to intraspecific competition [15]. In early stages, growth of $C$. rotundus is slow but in later stages it is found fastest particularly 30 to 45 Days after seeding. During this period C. rotundus shows high competitiveness for different crops. Juraimi and Begum observed that the sowing timing of Tef (Eragrostis tef (Zucc.) Trotter) played an important role in competitiveness of this crop when grown in $C$. rotundus infested field and delayed sowing of crop very critical with respect to the $C$. rotundus interference [39]. It was suggested that the delay of 7 and 15 days of sowing reduced plant height between $6.97-11.53 \%$, panicle length between $8.21-12.32 \%$ and grain yield up to $16 \%$.

The competitive ability of $C$. rotundus is due to its widespread tuber system. Research conducted by Iqbal et al., on the effect of number of tubers on morphological behavior 
of $C$. rotundus when different densities of tubers $(5,10,15$ and 20 tubers) were planted in pots revealed that shoot density was significantly increased $(78-151 \%)$ by increasing tubers numbers per pot compared with lower number of tubers [15]. Similarly shoot length, shoot biomass, underground biomass; number of tubers per pot and tubers weight was considerably increased with increasing the number of tubers up to 15 tubers per pot. However, 20 tubers per pot drastically reduced the vegetative structure of this plant. It is mainly because of intraspecific competition among the individual $C$. rotundus plants. Therefore the competitiveness of $C$. rotundus is depending upon the number of tubers to a certain limit and eventually increased with increasing in numbers of tubers.

\section{Response to Herbicides}

Inconsistency in dormancy of tubers is one of the reasons which make $C$. rotundus a noxious weed which reduce the effectiveness of different herbicides. Therefore it is important that herbicides applied should be absorbed through the shoot system and translocation of the chemical to the extensive tuber system. In early stages of growth it is relatively easy to control it; however, in later stages of growth it is rather difficult to eradicate the older plants because of extensive root and tubers system which developed after the damage of shoots. When tubers of $C$. rotundus treated with the combination of glyphosate and 2,4D (2,4-Dichlorophenoxyacetic acid), there was a $91 \%$ destruction of tubers after 30 days of spray. However, after 45 days of spray there was an increase in germination of tubers [40]. From these results it was concluded that effectiveness of auxinic herbicides (glyphosate and 2,4-D) may be temporary and $C$. rotundus rapidly recovered from the damages caused by these herbicide due to dormant stocks of tubers which sprouted in later stages when the effectiveness of herbicides diluted in the soil. As a non-selective herbicide, the timing of application of glyphosate to eradicate $C$. rotundus is important. For maximum control of $C$. rotundus for instance, glyphosate should be applied at flowering stages because translocation throughout the plant is limited before emergence of flowers. When applied at early stages of growth glyphosate only eradicate the aerial parts of plant and underground tubers and root systems escape the deleterious effect of herbicide. Best results with glyphosate only achieve 2-3 months after the initial emergence of $C$. rotundus which make this herbicide not suitable for agricultural purpose; however it can be used in lawn and other recreation centre where it used to eradicate this weed locally. In general, 2,4-D (3 kg /ha can kill 80 to $90 \%$ nutsedge) in combination of dicamba $(1 \mathrm{~kg})$ and glyphosate applied as a post emergence herbicides for the control of C. rotundus. Similarly repeated application of Glyphosate showed positive results against $C$. rotundus. A list of different selective and non-selective herbicides for the control of $C$. rotundus in different crops is listed on table 1 .

\section{Cultural control methods}

Most effective and common method of eradicating $C$. rotundus is hand weeding. However, this method is laborious and time consuming as well as is useless against $C$. rotundus because it removes only foliage parts and leaving tubers in the ground from which new plants appear rapidly. Therefore, it important the tuber of sprouting plant must be removed to control this weed. Similarly the traditional ploughing techniques are also useless because new plants can still grow from the damaged tubers. Extensive dormancy of tubers also prevents the effectiveness of ploughing and leads to rapid regrowth because it helps tubers to break their dormancy once they reached to the top soil. 
Table 1. Herbicides for control of $C$. rotundusin in different types of crops.

\begin{tabular}{|c|c|c|c|c|}
\hline Product & Active ingredient & Crop type & Application rate & Reference \\
\hline Certainty & Sulfosulfuron & Bermuda grass & $1.25 \mathrm{oz}$ per acre & $\begin{array}{l}\text { Brosnan and DeFrank, } \\
2008 \text { [5]. }\end{array}$ \\
\hline Primextra $500 \mathrm{FW}$ & atrazine + metolachlor & Summer crops & $1.8 \mathrm{~kg}$ a.i. $\mathrm{ha}^{-1}$ & $\begin{array}{l}\text { Mahmood and Cheema, } \\
2004 \text { [43]. }\end{array}$ \\
\hline Stomp 330EC & & Onion & $3 \mathrm{ml} \mathrm{m}^{-2}$ & Gul,et al., 2013 [44]. \\
\hline \multirow[t]{3}{*}{ Iso-proturon $50 \% \mathrm{SC}$} & & Onion & $1 \mathrm{~kg} / \mathrm{ha}$ & Ghosheh, 2004 [45]. \\
\hline & $\begin{array}{l}\text { Pendimethalin + } \\
\text { Prometryn }\end{array}$ & Maize & $1400 \mathrm{~g}$ a.i. $\mathrm{ha}^{-1}$ & Tahir, et al., 2009 [11]. \\
\hline & Dalapon & Cotton & $6.76 \mathrm{~kg}$ a.i. $\mathrm{ha}^{-1}$ & $\begin{array}{l}\text { Cheema, et al., } 1988 \\
\text { [13]. }\end{array}$ \\
\hline \multirow[t]{2}{*}{ Gramoxone } & Paraquat & Cotton & $600 \mathrm{~g}$ a.i. ha ${ }^{-1}$ & $\begin{array}{l}\text { Cheema, et al., } 1988 \\
\text { [13]. }\end{array}$ \\
\hline & S. metolachlor & Cotton & $2.15 \mathrm{~kg}$ a.i. $\mathrm{ha}^{-1}$ & $\begin{array}{l}\text { Iqbal and Cheema, } 2008 \\
\text { [3]. }\end{array}$ \\
\hline Buctril super $60 \mathrm{EC}$ & Bromoxynil +MCPA & Wheat & $0.45 \mathrm{~kg}$ a.i. $\mathrm{ha}^{-1}$ & Usman, et al., 2013 [46] \\
\hline Topik 15 WP & Clodinafop/propargyl & Wheat & 0.09 kg a.i. ha-1 & Usman, et al., 2013 [46]. \\
\hline Round up 490GL & Glyphosate & Summer crop & - & Iqbal et al., 2012 [15]. \\
\hline \multirow[t]{2}{*}{ Round up 490GL } & Glyphosate & -------- & $2.0 \mathrm{~kg}$ ai ha ${ }^{-1}$ & $\begin{array}{l}\text { Ameena and George, } \\
2004[40]\end{array}$ \\
\hline & 2,4-D Na salt & $\begin{array}{l}-------- \\
\end{array}$ & $1.75 \mathrm{~kg}$ ai ha ${ }^{-1}$ & $\begin{array}{l}\text { Ameena and George, } \\
2004 \text { [40]. }\end{array}$ \\
\hline Macete $60 \mathrm{EC}$ & Butachlor & Rice & $1.178 \mathrm{~kg} \mathrm{ha}^{-1}$ & Raza, et al. (2011[1]) \\
\hline Xinchlor 50 EC & Acetachlor & Rice & $0.125 \mathrm{~kg} \mathrm{ha}^{-1}$ & Raza, et al., 2011 [1]. \\
\hline Sunstar & Ethoxy sulfuron & Rice & $0.2 \mathrm{~kg} \mathrm{ha}^{-1}$ & Raza, et al., [1] \\
\hline $\begin{array}{l}\text { Puma Super 6.9\% } \\
\text { EW }\end{array}$ & Fenoxaprop-p-Ethyl & Rice & $625-750 \mathrm{~mL} \mathrm{ha}^{-1}$ & Raza, et al., 2011 [1]. \\
\hline
\end{tabular}

Application of plastic sheet mulch for $C$. rotundus control is not effective because the piercing shoot tip of plant can simply penetrate it. Experiments conducted by Bangarwa et al. on application of different cultural methods on density of tubers of $C$. rotundus in bell pepper organic farming systems [41]. In their experiments they used green polyethylene film, clear polyethylene film, turnip followed by green polyethylene film, turnip followed by clear polyethylene film, tillage every $3 \mathrm{wk}$, and fallow. The results of this experiment indicated that regular tillage and use of a polyethylene film resulted in a lower density of large tubers. In case of hand-weeded plots most of tubers were small in size ranging from 25 to 194 viable tubers $\mathrm{m}^{-2}$. However frequent tillage or use of a translucent polyethylene film showed no effectiveness in eradicating $C$. rotundus over two growing seasons. From these results it was concluded that for proper controlling of $C$. rotundus season-long management is essential.

\section{Biological Control}

The inadequate effectiveness of chemical herbicide against $C$. rotundus tubers and other modified underground parts opened the way for the search of alternative preventive measures. Similarly chemical herbicides also affect non target plant species as well as public concern regarding environmental problems associated with chemical pesticide usage. Unfortunately the application of biological control agents is a lengthy process and users cannot get the desirable results in a short period, therefore it did attract the farmers who are used to 
indulging in quick results. During the last decade of previous century there were several promising bio-herbicide were discovered which were claimed to be alternative sources of chemical herbicides for the control of different weeds. However, when these bio-herbicides applied in the agricultural fields they did not provide adequate results therefore these bioherbicides lost the public attention rapidly. Although working on different fungal pathogens as bio-herbicides against noxious weeds we came with better understanding about the biology of these weeds and their relations with these natural enemies. Trials conducted in greenhouse, on the impacts of Dactylaria higginsiia fungal pathogen, on $C$. rotundus, Kadir and Charudattan concluded that this pathogen have potential to be used as a bio-herbicide agent against this weed [42]. Under greenhouse trails inoculation with conidial suspensions of $D$. higginsil showed significant reductions in shoot numbers (72\%), shoot dry weight (73\%), and tuber dry weight $(67 \%)$ of $C$. rotundus 45 days after inoculation.

\section{Acknowledgement}

We are grateful to Mr. Amanullah Ronjha, Additional Registrar of Lasbela University of Agricultural, Water, and Marine Sciences, Uthal, Lasbela for providing transport facilities for field survey of District Lasbela.

\section{References}

1. Raza S, Akbar N, Kausar R, Arif MS, \& Shahzad SM (2011). Effect of different weed control practices in district sown rice (Oryza sativa L.). International Journal of Agricultural and Applied Sciences, 3(1), 21-26.

2. Rao VS (2000) Principles of weed science $\left(2^{\text {nd }} E d.\right) 72$.

3. Iqbal J \& Cheema ZA (2008). Purple Nutsedge (Cyperus rotundus L.) management in cotton with combined application of sorgaab and S-Metolachlor.
Pakistan Journal of Botany, 40(6), 23832391.

4. $\quad$ Sivapalan SR \& Jeyadevan P (2012). Physico-chemical and Phyto-chemical Study of Rhizome of Cyperus rotundus Linn. International Journal of Pharmacology and Pharmaceutical Technology, 1(2), 42-46.

5. Brosnan JT \& DeFrank J (2008). Purple Nutsedge Control in Turf and Ornamentals. Landscape (revised) Jan. 2008. Cooperative Extension Service/CTAHR, University of Hawaii at Mänoa, Honolulu, Hawaii.

6. Flora of Pakistan online: http://www.efloras.org/florataxon.aspx?flora _id=5\&taxon_id=200026713 (Accessed 13 ${ }^{\text {th }}$ August 2014).

7. Lati RN, Filin $\mathrm{S} \&$ Eizenberg $\mathrm{H}$ (2011). Temperature- and radiation-based models for predicting spatial growth of purple nutsedge (Cyperus rotundus). Weed Science, 59(4), 476-482.

8. Javid A, Bajwa R, Rabbani N \& Anjum T (2007). Comparative tolerance of rice (Oryza sativa L.) genotypes to purple nutsedge (Cyperus rotundus L.) allelopathy. Allelopathy Journal, 20(1), 157-166.

9. Travlos IS, Economou G, Kotoulas VE, Kanatas PJ, Kontogeorgos, AN \& Karamanos AI (2009). Potential effects of diurnally alternating temperatures and solarization on purple nutsedge (Cyperus rotundus) tuber sprouting. Journal of Arid Environment,73, 22-25.

10. Shabana YM, Charudattan R, AbouTabl AH, Morales-Payan JP, Rosskopf EN \& Klassen W (2010). Production and application of the bioherbicide agent Dactylaria higginsii on organic solid substrates. Biological Control, 54, 159-165.

11. Tahir M, Javed MR, Tanveer AM, Nadeem A, Wasaya A, Bukhari SAH \& Rehman J (2009). Effect of Different 
Herbicides on Weeds, Growth and Yield of Spring Planted Maize (Zea mays L.). Pak. j. life soc. sci., 7(2), 168-174.

12. Qureshi R (2004). A quantitative account of weeds of sugarcane (Saccharum officinarum) crop in District Sukker. Science Vision, 9(1-2) (3-4), 1-4.

13. Cheema ZA, Ahmed S \& Wahla AJ (1988). Chemical weed control in cotton (Gossypium hirsutum L.). Pakistan Journal of Agriculture Science, 25(4), 339-348.

14. Riaz T, Khan SN \& Javaid A (2009). Weed flora of Gladiolus fields in district Kasur, Pakistan. The Journal of Animal and Plant Science, 19(3), 144-148.

15. Iqbal J, Hussain S, Ali A \& Javaid A (2012). Biology and Management of Purple Nutsedge (Cyperus rotundus L.) The Journal of Animal \& Plant Sciences, 22(2), 384-389.

16. Keeley PE (1987). Interference and interaction of purple and yellow nutsedges (Cyperus rotundus and C. esculentus) with crops. Weed Technology, 74-81.

17. Santos BM, Morales-Payan JP, Stall WM \& Bewick TA (1998). Influence of purple nutsedge (Cyperus rotundus) density and nitrogen rate on radish (Raphanus sativus) yield. Weed Science, 46, 661-664.

18. Singh SP (1968). Presence of a growth inhibitor in the tubers of Cyperus rotundus. Proceedings, Indian Academy of Science,67, 18-23.

19. Meissner R, Nel PC \& Smith NSH (1979). Influence of Cyperus rotundus on growth and development of some crop plants. Proceedings of 3rd National Weed Conference of South Africa, 39-52.

20. Verma R, Rao PB \& Rawat YS, (2002). Allelopathic effects of certain weed extracts on seed germination of ten varieties of the genus Brassica. Nature and Biosphere, 7(1-2), 26-33.
21. Alsaadawi IS \& Salih NMM (2009). Allelopathic potential of Cyperus rotundus L. Interference with crops. Allelopathy Journal, 23(1), 40-46.

22. Quayyum HA, Malik AU, Leach DM \& Gottardo C (2000). Growth inhibitory effects of Cyperus rotundus on rice seedlings. Journal of Chemical Ecology, 26, 2221-2231.

23. Komai K, Tang CS \& Nishimoto RK (1991). Chemotypes of Cyperus rotundus in Pacific Rim and Basin: Distribution and inhibitory activities of their essential oils. Journal of chemical ecology, 17(1), 1-8.

24. Rice EL (1984). Allelopathy. Academic Press, New York.

25. Nagulendran KR, Velavan S, Mahesh R \& Hazeena Begum V (2007). In vitro antioxidant activity and total polyphenolic content of Cyperus rotundus rhizomes. E-Journal of Chemistry, 4(3), 440-449.

26. Kilani S, Ledauphin J, Bouhlel I, Ben Sghaier M, Boubaker J, Skandrani I, Mosrati R, Ghedira K, Barillier D \& ChekirGhedira L (2008). Comparative study of Cyperus rotundus essential oil by a modified GC/MS analysis method. Evaluation of its antioxidant, cytotoxic, and apoptotic effects. Chemistry and Biodiversity, 5, 729-742.

27. Kilani-Jaziri S, Neffati A, Limem I, Boubaker J, Skandrani I, Sghair MB, Bouhlel I, Bhouri W, Mariotte AM, Ghedira K, Dijoux Franca MG, Chekir-Ghedira L (2009). Relationship correlation of antioxidant and antiproliferative capacity of Cyperus rotundus products towards K562 erythroleukemia cells. Chemico-Biological Interactions, 181, 85-94.

28. Raut NA \& Gaikwad NJ (2007). Anti-diabetic activity of hydroethanolic extract of Cyperus rotundus in alloxan 
induced diabetic in rats. Fitotrapia, 77, 585588.

29. Uddin SJ, Mondal K, Shilpi JA \& Rahman MT (2006). Antidiarhoeal activity of Cyperus rotundus. Fitoterapia, 77, 134136.

30. Weena $\mathrm{H}$, Nkhunya $\mathrm{MH}$, Bray $\mathrm{DH}$, Mwasumbi LB, Kinbo LS \& Kilimali VA (1990). Antimalarial activity of Tanzanian medicinal plants. Plants Medica, 56, 368370.

31. Gupta MB, Palik TK, Singh N \& Bhargava KP (1971). Pharmacological studies to isolate the active constituents from Cyperus rotundus possessing antiinflammatory antipyretic and analgesic activities. Indian Journal of Medical Research, 59, 76-82.

32. Elizabeth MW (2002). Major Herbes of Ayuveda. Elsevier Health Science.

33. Chen Y, Wang X, Liu J \& Huang L (2011). Anti-dysmenorrhea components from the rhizomes of Cyperus rotundus Linn. (Cyperaceae). 8th OAPS Working Paper Series, 1-6.

34. Bhattarai NK (1993). Folk herbal remedies for diarrhea and dysentery in central Nepal. Fitoterapia, 64, 243-250.

35. Yang YL, Chang FR, Wu CC, Wang WY \& Wu YC (2002). New ent-kaurane diterpenoids with anti-platelet aggregation activity from Annona squamosa. Journal of Natural Product, 65, 1462-1467.

36. Seo EJ, Lee DU, Kwak JH, Lee SM, Kim YS \& Jung YS (2011). Antiplatelet effects of Cyperus rotundus and its component (+)-nootkatone. Journal of Ethnopharmacology, 135, 48-54.

37. Nima ZAM, Jabier MS, Wagi RI \& Hussain HAK (2008). Extraction, Identification and Antibacterial activity of Cyperus oil from Iraqi $C$. rotundus.
Engineering \& Technology, 26(10), 11561163.

38. Outtara B, Simard R, Holley R \& Piette A (1997). Antimicrobial activity of selected fatty acid and essential oils against six meat spoilage organisms. Int. J. Food Microbial. 37, 155-162.

39. Juraimi AS \& Begum M (2009). Competition Effects of Date of Sowing and Nutsedge Removal Time on Yield and Yield Contributing Characters of Tef [Eragrostis tef (Zucc.) Trotter]. American Journal of Applied Science, 6(10), 1820-1825.

40. Ameena M \& George M. (2004). Control of purple nutsedge (Cyperus rotundus L.) using glyphosate and 2,4-D sodium salt. Journal of Tropical Agriculture, 42(1-2), 49-51.

41. Bangarwa SK, Norsworthy JK, Jha P \& Malik M (2013). Purple Nutsedge (Cyperus rotundus) Management in an Organic Production System. Weed Science 61(2), 239-243.

42. Kadir J \& Charudattan R (2000). Dactylaria higginsii, a Fungal Bioherbicide Agent for Purple Nutsedge (Cyperus rotundus). Biological Control, 17(2), 113124.

43. Mahmood A \& Cheema ZA (2004). Influence of Sorghum Mulch on Purple Nutsedge (Cyperus rotundusL.). International Journal of Agriculture and Biology, 6(1), 86-88

44. Gul B, Khan IA, Hussain Z \& Saeed M (2013). Impacts of soil solarization combined with other weed control strategies on weed management in onion nurseries. Pakistan Journal of Weed Science Research, 19(1), 101-108.

45. Ghosheh H (2004). Response of vegetable weeds to different post-emergence herbicides. Crop Protection, 25(3), 172-175. 
Baloch et al.

46. Usman K, Khan MQ \& Rehman A (2013). Integrated impact of tillage and herbicides on weed control and wheat yield in cotton based cropping system. Sarhad Journal of Agriculture, 29(4), 495-501. 